\title{
TWO PERSPECTIVES ON CARING RESEARCH: RESEARCH ON WELL-BEING AND RESEARCHER WELL-BEING
}

\author{
Kaarina Määttä, Satu Uusiautti \\ University of Lapland, Rovaniemi, Finland \\ E-mail: Kaarina.Maatta@ulapland.fi, satu_uusiautti@hotmail.com
}

\begin{abstract}
Caring research is a new concept that is discussed and defined from two supplementary perspectives: (1) as research aiming at promoting well-being and (2) as a caring research community that cares for the researcher well-being and reciprocal relationships between colleagues and between supervisors and students. These dimensions are discussed in the light of the latest findings and theories of positive psychology as well as based on the authors' studies in the field. The caring research ideology contributes a comprehensive viewpoint to the world of academic research because it also pays attention to the actual research process within the research community. This well-being focused approach can serve as a means to flourish within the ever-increasing demands of the academic world.
\end{abstract}

Key words: caring research, positive psychology, researcher well-being, supervision, well-being at work.

\section{Introduction}

Many of us involved in research have faced the current tendency in the academic world: competition for research funding between universities and individual researchers and research groups, prompt graduation and study processes among university students, and demands on high-quality yet the-faster-the-better publication of research results among graduates and researchers are characteristics that seem to determine the way research is conducted in these days. "[A]lmost all academic research I had known is funded through tedious grant requests, annoying peer reviews, officious bureaucracy, unconscionable delays, wrenching revisions, and then rejection and heart-stopping budget cuts", Prof. Seligman said about the state of academic research in his preface of Flourish $(2011$, p. 6).

Indeed, high pressures for measurable results have been described, for example, by Roth (2002) who used the term "publish or perish" when referring to professors' careers. Publishing should be international, too, because these "seafarers" produce much more funding to universities than "islanders" who prefer working within the borders of their own nation (Kubiatko, 2013). Likewise, reading and citing readings in grant proposals or reports are considered crucial (Tenopir, Mays, \& Wu, 2011). At the same time, universities compete for talented applicants and many universities have to think about methods to increase their attractiveness in the eyes of students, their future researchers in order to stay competitive (Määttä, Uusiautti, \& Määttä, 2014). How to do that if the message mainly delivered tells about tightening pressures, competitive atmosphere, and pure self-interest among researchers?

Likewise, new kinds of expectations are targeted to research, too. Today's societal changes, globalization, and uncertainty about the future shaken the well-being of people and communities (Diener, 2009). Research should provide answers to how to face the future without people losing trust in their own abilities to survive and solve threats of well-being (e.g., Cohn \& Fredrickson, 2010). People have always looked for happiness and success in their lives, and this goal has not become any less significant in the lives of modern people. 
Kaarina MÄÄTTÄ, Satu UUSIAUTTI. Two perspectives on caring research: Research on well-being and researcher well-being

PROBLEMS

OF EDUCATION

IN THE $21^{\text {st }}$ CENTURY

Volume 66,2015

\section{Problem of Research}

The aforementioned two current challenges made us think about the concept of caring research. The concept was born based on (1) the authors' research work after being involved in positive psychological research for several years and (2) collaboration in the authors' research team: the mutual support, encouragement, and productivity even within a current competition situation stirred interest in us and we decided to analyze it further. The purpose of this study is to discuss: what is caring research and how to define it?

In the authors' researcher team, many researchers had to choose research themes that pursue enhancing good quality of life humanly and socially; in other words, themes illustrating mutual care and concern that provide the foundation for well-being in individual people and communities. Wish to influence positively and trust in human strengths also reflected on the interaction within the research group. The researchers showed that feeling positive emotions toward work produced not only a quantitative improvement by increasing efficiency, but also a qualitative one by making a better outcome that results from the virtue of pride, belief, and commitment to one's job.

\section{Research Focus}

How to reach satisfaction and optimal performances and quality research by enhancing positive feelings and states at universities (see also Isen \& Reeve, 2006; Winter \& Sarros, 2002) is the question viewed through the concept of caring research.

\section{Caring Research}

\section{Positive Psychology as the Basis of Caring Research}

Caring research is viewed here based on the ideas of positive psychology. Gable and Haidt (2005) briefly define positive psychology in the following terms: "Positive psychology is the study of the conditions and processes that contribute to the flourishing or optimal functioning of people, groups, and institutions" (p. 104). The aim of positive psychology is to study the reasons why people feel joy, show altruism, and create healthy families and institutions.

Research themes such as well-being, happiness, quality of life, and positive feelings have been introduced by positive psychology, which has provided research concerning not only positive characteristics and feelings, but also the institutions that enhance the discovery of positive feelings and strengths (Seligman et al., 2005). The branch of positive psychology is concerned with facilitating good lives and enabling people to be at their best (see, e.g., Achor, 2010; Csikszentmihalyi, 2008; Linley, Willars, \& Biswas-Diener, 2009; also Uusiautti \& Määttä, 2015) - research that aim at positive influence (see also Beveridge, 2005; Seligman, 2009).

In addition to its positive purposes, caring research can be defined as a positively-perceived research process constituting of supportive and trustful interaction and relationships, illustrating positive organizational behaviors (e.g., Luthans, 2002; Rego, Ribeiro, Pina, \& Jesuino, 2011; Uusiautti \& Määttä, 2013a). These dimensions will be defined next.

\section{Dimensions of Caring Research}

What is caring research, then? It is possible to understand the concept as follows: (1) caring research as research aiming at promoting well-being and (2) caring research as research work manifested by mutual support, encouragement, and collaboration between researchers. The former focuses on themes promoting a good quality of life and well-being. This kind of 
research is interested in, for example, discovering elements of reciprocal care and help among human beings, structures of positive development, and opportunities to use human strengths and draw from positive resources, as well as the bases of flourishing communities and societies. However, as the latter element suggests, caring research is not just about caring the research target. As we see it, caring research is conducted by researchers who share the interest in and enthusiasm about positive influencing and mutual care. Thus, caring research appears as the joy and opportunity to do research together in an open and supportive academic environment. Caring research comes true in respectful collaboration between researchers, supervisors, students, and other experts at every phase of research work.

When the aforementioned two viewpoints are put together, the caring research approach covers all aspects of a research process. Next, we will discuss in detail what these dimensions of caring research entail. We will present examples of caring research themes as well as of caring research community.

\section{Caring Research Themes}

Caring research wants to promote the well-being of people and communities. This interest can be further discussed as several research themes. Next, some important well-being-focused themes are discussed, such as resources in the human lifespan and positive development, positive emotions as the source of well-being, well-being after crises and adversities, as well as resources in work and professional development, and organizational well-being. The following themes are based on the authors' studies and interests in the field of positive psychological research.

\section{Resources as the Foundation of Positive Development and Achievements}

Lifespans of people who could be considered positive examples from whom we could learn and benefit others (e.g., Magnusson \& Mahoney, 2006). It is, therefore, relevant to analyze whether the lifespans of positively acting people differ from those of others, and, if they do, to find out how (Uusiautti \& Määttä, 2015). This kind of research pursues determine the elements of positive development along human beings' lifespans.

For example, child research can be defined (see Uusiautti \& Määttä, 2013b) as research about, with, and by children (see Alderson, 2001; Mayall, 2008), and especially, for children (Prout, 2005). Questions of how to enhance children's growth and development, and for example, their discovery and use of signature strengths (Seligman, 2011) illustrate approaches in which researchers' interests are in positively-focused research for children. Actually, the need for such research is recognized and well-justified: according to Seligman (2009), it would function not only as a buffer against malaise and depression but also increase life satisfaction and well-being, promote learning quality, academic success, and creative thinking, enhance the emergence of supportive adult-child and peer relationships, and increase tolerance of diversity (see also Huebner et al., 2009; Schreiner, Hulme, Hetzel, \& Lopez, 2009; Webster-Stratton \& Reid, 2004).

This approach as caring research and well-being promoting research is to study how people can reach achievements and succeed by using positive resources. Some examples of positive strategies and courses of lives in individuals are introduced by studies about straight-A students' lives (Salmela \& Uusiautti, 2013), female leaders' career developments (Hyvärinen, Uusiautti, \& Määttä, 2015), long-lasting marriages (Määttä, Anglé, \& Uusiautti, 2014), awarded top workers' lifespans (Uusiautti, 2008; Uusiautti \& Määttä, 2015), and in lifelong learning (Purtilo-Nieminen \& Määttä, 2011). 
Kaarina MÄÄTTÄ, Satu UUSIAUTTI. Two perspectives on caring research: Research on well-being and researcher well-being

PROBLEMS

OF EDUCATION

IN THE $21^{\text {st }}$ CENTURY

Volume 66, 2015

32

\section{Positive Emotions as the Source of Well-being}

Sixthly, positive emotions also make an important research theme and connect caring research with well-being. "Moods and emotions, which together are labeled affect, represent people's on-line evaluations of the events that occur in their lives" (Diener et al., 1999, p. 277). For example, Fredrickson's (2001) broaden-and-build model of positive emotions explains why the propensity to experience positive emotions has evolved into a ubiquitous feature of human nature and how positive emotions might be tapped to promote individual and collective wellbeing and health. According to Isen (2003; see also Isen \& Reeve, 2006), positive feelings sustain intrinsic motivation and help with successfully performing pleasing work tasks and new challenges as well as enjoying them. Positive emotions serve as markers of flourishing or optimal well-being (Fredrickson, 2001), and research on experiences can be useful for measuring well-being (Kahneman \& Krueger, 2006; Kahneman et al., 2004).

In educational contexts, joy of learning (see, e.g., Lähteenmäki, 2013; Rantala \& Määttä, 2011) has been a topical research theme. Similarly, in Finland (Keskitalo, Uusiautti \& Määttä 2013; Uusiautti \& Määttä 2014) and abroad (e.g., Craven \& Bodkin-Andrews, 2006; Purdie et al., 2000; Sandage, Seminary, Hill, \& Vang, 2003) positive psychological approaches have been used for finding means to enhance indigenous peoples' well-being and flourishing. Our perspective is bound to educational and psychological research paradigms. However, we believe that whatever the paradigm, genuine aspirations to conduct ethically sustainable and positivelytoned research naturally aim at benefitting the research target or phenomenon.

\section{Well-being after Crises and Adversities}

Caring research does not close eyes from difficulties, hardships, or crises. Instead, it is relevant to study how people can overcome these kinds of challenging situations and crises and what the role of positive strategies and strengths are in these events and processes (see e.g., Ryff \& Singer, 2003).

Special topics can be named with quite a wide range: surviving with various states such as anorexia (Savukoski, Määttä, \& Uusiautti, 2014), narcolepsy (Karjalainen, Nyrhilä, Määttä, \& Uusiautti, 2013), or other illnesses and health problems (e.g., Aspinwall \& Tedeschi, 2010; Tugade, Fredrickson, \& Feldman Barrett, 2004); surviving with various developmental disorders, such as autism (Kangas, Uusiautti, \& Määttä, 2012) or reading difficulties (Vanninen \& Määttä 2013); and surviving with various events and situations in life, such as bullying at school (Hoisko, Uusiautti, \& Määttä, 2014), grief and death (e.g., Bosticco \& Thompson, 2005; Stein, Trabasso, Folkman, \& Richards, 1997), war (e.g., Ai, Tice, Whitsett, Ishisaka, \& Chim, 2007; Hobfoll et al., 1991), and crimes (Davis, Hoffman, \& Quigley, 1988; Jiang \& Winfree, 2006; Äärelä, Uusiautti, \& Määttä, 2014).

\section{Organizational Well-being and Professional Development}

Work forms a major part of most people's daily lives, and therefore, it is important to study flourishing at work and opportunities to develop professionally so that work could become a source of satisfaction and self-fulfillment in life. Examples of such positive studies related to work are analyses of awarded Finnish top workers and their positive development (Uusiautti, 2008) and the success of enterprises (Uusiautti, 2015) as well as continuing education among the unemployed (Pietilä-Litendahl \& Uusiautti, 2014). We have also studied the professional development of vocational teachers (Koski-Heikkinen, Määttä, \& Uusiautti, 2014), early childhood education teachers (Happo, Määttä, \& Uusiautti, 2012), elementary education teachers (Uusiautti \& Määttä, 2013c, 2013d), and special education teachers (Lakkala, Uusiautti, \& Määttä, 2014; Sipilä \& Määttä, 2011). 
At an institutional level, it is equally important to study how institutions can enhance human beings' positive behaviors and development, and well-being by caring. Organizational psychological constructs can either increase or impede the experiences of positive emotions and subjective well-being (e.g., Diener, Oishi, \& Lucas 2009). Numerous studies focus on finding out positive organizational behaviors, leadership processes, and well-being promoting activities and work arrangements (e.g., Bakker \& Schaufeli, 2008; Luthans, Avolio, Avey, \& Norman, 2007; Syväjärvi et al. 2014; Uusiautti, 2013).

\section{A Caring Research Community}

The second viewpoint to caring research is related to the conductors of the research and to the research community. There are many ways of approaching this issue.

\section{Psycho-social Dimensions of Research Work and Community}

Turner, Barling, and Zacharatos (2002) illustrated the psycho-social elements of a work community with a theory called "the Healthy Work Model" (HWM). Healthy work systems require good external environments and develop strategies for good work practices (e.g., autonomy, teamwork, and leadership) that enhance positive psychological processes and other mechanisms (e.g., trust, perceived control, and organizational commitment) in order to increase healthy outcomes (e.g., well-being and proactivity). Likewise, according to Rego et al. (2011), fostering organizational virtuousness (e.g., through honesty, interpersonal respect, and compassion) improves workers' affective well-being and promotes a more committed workforce. When considering caring research, it is, however, worth noticing that while research work per se can be the most motivating and satisfying, the work environment includes numerous agents and elements that need to be considered (see e.g., Houston, Meyer, \& Paewai, 2006; Winter \& Sarros, 2002).

The caring research approach can, thus, be identified within the research on positive organizational behavior (POB) (see Luthans, 2002; Youssef \& Luthans, 2007). Luthans (2002) defines POB as "the study and application of positively oriented human resource strengths and psychological capacities that can be measured, developed, and effectively managed for performance improvement in today's workplace" (p. 59).

\section{Collaboration among Researchers}

The support and encouragement from colleagues can be of irreplaceable value not only for a worker's own success and well-being at work, but also for the well-being and success of the whole work unit or work community. However, an academic community does not always represent such a positive work environment as described above. Competition, self-interest, and belittling of other's achievements lead to hostile academic work environment and suspiciousness between researchers (see e.g., Kramer, 1999). It is difficult to build co-operation between the research staff when the situation has already gotten out of hand and mistrust is the dominating attribute of the community.

Ferres, Connell, and Travaglione (2004) point out, how at its best, working together, helping each other, and pursuing shared goals can provide researchers' with a sense of meaning that we referred to already in the introduction of this article. Perceived meaningfulness covers positive outcomes in one's own and co-workers' well-being (Liu, Siu, \& Shi, 2010). Perceiving this positive outcome can act as a significant component of common good and well-being alongside the positive achievements in research work. Indeed, perceived meaningfulness is connected with a sense of meaningful doing, often manifested as flow that is an autotelic experi- 
Kaarina MÄÄTTÄ, Satu UUSIAUTTI. Two perspectives on caring research: Research on well-being and researcher well-being

PROBLEMS

OF EDUCATION

IN THE $21^{\text {st }}$ CENTURY Volume 66, 2015

34

ence, total feeling of becoming absorbed by one's doing and that contributes to one's perception of satisfaction with life (Csikszentmihalyi, 2008).

\section{Positive Atmosphere in Research Teams}

There are numerous studies that discuss ways to alleviate the tense atmosphere in workplaces. The caring research approach draws from the positive. For example, Kinjerski and Skrypnek (2006) have listed factors that are associated with individuals' experiences of spirit at work. Factors vary from inspiring and supportive leadership practices to shared vision and purpose as well as an intention to contribute to the overall good of society, and from positive workplace culture to positive connections between all members and a sense of community in the organization, not forgetting opportunities for members to pursue professional and personal growth and to fulfill their own personal mission through work, and appreciation and regard for the contributions made by its members (Kinjerski \& Skrypnek, 2006, pp. 290-291)

According to the study of Winter and Sarros (2002) in Australian universities, an academic work environment is motivating when roles are clear, job tasks are challenging, and supervisors exhibit a supportive leadership style. They suggest that in universities, "a crucial leadership challenge for heads of departments is to assign job tasks efficiently and effectively (managerial values) while recognising and maintaining the importance of professional job growth and collegial relations (academic values)" (Winter \& Sarros, 2002, p. 255) and conclude that "[b]y demonstrating support for staff motivation, leaders can establish a context whereby academics feel more inclined to help the university reach its goals" (Winter \& Sarros, 2002, p. 256). According to several studies (see, e.g., Egan et al., 2009; Kezar \& Kinzie, 2006; Mayya \& Roff, 2004), good and supportive atmosphere makes research work seem meaningful and inspiring.

\section{Writing and Publishing Together}

According to Kramer (1999), mutual trust has a number of important benefits for organizations and their members, and this applies to the academic communities as well. A good practical example of the open-minded collaboration in the sense of caring research is writing and publishing together with colleagues about one's own or the team's joint research and related findings (see also Uusiautti, 2014). In the field of educational sciences, research work often represents itself downright a one-man-effort, working alone in a researcher's chamber with a laptop as the only company. Writing research articles tends to follow this pattern of lonely toil; the mistrust between researcher colleagues and fear of someone stealing your ideas being not the least of worries inhibiting collaboration (cf. e.g., Kramer, 1999; McAllister, 1995). However, co-writing can be very beneficial. First, your own analyses and conclusions can become more profound than if you were writing along. Overall, having a trustworthy colleague read your text is beneficial. Within a team, you can find possibilities in your data that can lead to true innovations, new concepts, theories, and illustrations, or even new fields. Likewise, teamwork can ease the pain of working with the paper after getting reviews; sharing the work makes the work seem lighter. It is also wise to reflect on the reviewers' comments and their aptness with your co-authors: the criticism may not be that crushing when you do not have to wonder them by yourself. Finally, if and when the paper becomes accepted, the joy becomes doubled when writing in team. Happy events are experienced more positively with other people (Seligman, 2011) due to human beings' social nature (Bercheid, 2003). 


\section{Supervision}

Changes in the university education also necessitate special attention to the training of PhD students (Enders, 2005). Caring supervision is important both in doctoral research and post-doctoral research. Frank Pajares claimed already in 2001 that construct drawn from positive psychology can well explain student achievement and overall positive self-confidence and optimism: he also pointed out that "such students are more likely to regard themselves and to show regard to others" (Pajares, 2001, p. 34). According to Kezar and Kinzie (2006), quality begins with an organizational culture that values high expectations and shows respect for diverse learning styles, and where instruction builds in active learning, assessment and prompt feedback, collaboration, adequate time on task, and out of class contact with faculty.

University-level studies are demanding and students need special support and guidance (Egan et al., 2009). In her studies on the supervision of doctoral theses, Määttä (2012) represented that the supervisor's resources can be divided into four dimensions of Will, Knowledge, Actions, and Proficiency, each contributing to the supervision relationship. Will means the supervisor's commitment to supervision, whereas knowledge refers to the substance knowledge and/or the mastery and ability to comprehend the overall structure. Actions are to ensure that the contents meet the scientific quality requirements. Proficiency comprises positive and supportive supervision methods and personality. A supervisor can emphasize different features depending on his or her own style and on the student's work habits and needs (see Richardson, 2005). Supervision is not likely to succeed if one of the aforementioned resources is completely missing.

The caring research approach covers all phases of supervision, but only if supervisors are willing to adopt the caring attitude drawing from the recognition of human strengths and well-being. Supervision can develop in the positive direction if university teachers and professors evaluate their own development as supervisors (Emilsson, 2007), reflect on and diversify supervision practices (McCallin \& Nayar, 2012), and plan supervision together with students to enhance their inspiration and opportunities to succeed in research (Manathunga, 2005).

Based on her practical experience and research, Määttä (2012) has introduced the pedagogy of supervising doctoral thesis and pointed out that during the dissertation process, the relationship between the supervisor and the doctoral student changes and varies. A supervisor has to help a PhD student discreetly in a constructive and respective manner. How to be a critical but safe mirror for a PhD student who struggles with his or her research? Along with the research process, the ability to supervise and to be supervised becomes constantly challenged, too (Määttä, 2012).

But, as the supervision relationship is reciprocal, it is also important that the $\mathrm{PhD}$ student thinks of thanking the supervisor for good guidance (Määttä, 2014). Mutual gratitude and appreciation are likely to increase the sense of well-being in the partners of the supervision relationship (see, e.g., Otake et al., 2006), which we argue to be one of the important factors of caring research.

\section{Caring Research is an Attitude and a Way of Action Needed in Today's Research Work}

In research, a healthy and fair competition is good and necessary for the development of science itself (e.g., as competition for research funding through evaluation of research plans), but the pressures for finding funding, publishing, and reaching achievements can turn against themselves easily. Rigorous peer-reviews, critical expert evaluations, and strict funding application processes cannot mean that they have to be devastating, embarrassing, and partialquite the opposite (Uusiautti, 2015). There are, for example, certain ethical rules that Benos 
Kaarina MÄÄTTÄ, Satu UUSIAUTTI. Two perspectives on caring research: Research on well-being and researcher well-being

PROBLEMS

OF EDUCATION

IN THE $21^{\text {st }}$ CENTURY

Volume 66, 2015

et al. (2003) call "the etiquette of review" that every scientific referee, regardless of academic discipline, must strictly follow, including, for example, an honest, critical assessment of the research; confidentiality about the existence and substance of the manuscript; avoidance of any conflicts of interest; and a collegial, constructive manner of giving feedback (Benos et al., 2003). The academic community should follow these principles more widely in research collaboration, not just regarding reviews of article manuscripts. Caring research is, therefore, about mutual respect and positive elements in researcher interaction, such as honesty, trustworthiness, confidentiality, and constructiveness that are not only connected with better relationships at the work unit and higher engagement, but also with high-quality work outcomes (see Ferres, Connell, \& Travaglione, 2004; Schofield, 1998; Uusiautti \& Määttä, 2015), high-quality research in this case.

This leads us to the conclusion of how the caring research approach affects the quality of research. Caring research does not adopt any particular methodology or data collection technique, but critically questions and reflects on all aspects of the research process (cf. also Darbyshire, MacDougall, \& Schillerp, 2005), including research ethics (e.g., Knapp \& VandeCreek, 2006). We suggest that researchers should develop a set of strategic values that guide their decision and action as researchers (see also Teddlie \& Tashakkori, 2003). It is necessary to contemplate how to find suitable ethical working methods for the research. There is not just one exact answer to this question: all depends on the research context, target, and select method (Creswell, 2009). Naturally, the authors' viewpoint is based on research work in educational and behavioral sciences, and especially, in positive psychology. This orientation has influenced the way the concept of caring research is discussed here. However, it has also provided a very important approach to view research in general, namely the one seeing research as an arena of caring, flourishing, cooperation, and well-being.

Eventually, caring research is merely about an attitude that one adopts when acting as a part of the academic community than any approach typical of one specific field of research. The conclusion is that caring research means profoundly quality research because this approach covers not only the research work targeted to investigate a phenomenon or target, but also the wider context where the research is conducted, especially referring to the well-being producing potential that lies in the collaboration between researchers (including students and supervisors) - if only we are brave enough to trust each other and indulge in the joy of doing research together.

This idea is based on the finding that positive experiences about one's own doing make for one of the most central dimensions of good performance (Uusiautti \& Määttä, 2015; see also Liden, Wayne, \& Sparrowe, 2000). Thus, caring research does not shun achievements, competition, or struggle, but reminds the academic community of the possibilities of positive collaboration (see also Achor, 2010; Myers \& Diener, 1995). Indeed, Quick (1999) has also pointed out the connection between feeling good and high performance, and their contribution to high levels of well-being. At its best, caring research can become a means to find well-being and to increase well-being through research.

\section{References}

Achor, S. (2010). The happiness advantage. The seven principles of positive psychology that fuel success and performance at work. New York, NY: Crown Business.

Ai, A. L., Tice, T. N., Whitsett, D. D., Ishisaka, T., \& Chim, M. (2007). Posttraumatic symptoms and growth of Kosovar war refugees: The influence of hope and cognitive coping. The Journal of Positive Psychology, 2 (1), 55-65.

Alderson, P. (2001). Research by children: rights and methods. International Journal of Social Research Methodology: Theory and Practice, 4 (2), 139-153. 
Aspinwall, L. G., \& Tedeschi, R. G. (2010). The value of positive psychology for health psychology: Progress and pitfalls in examining the relation of positive phenomena to health. Annals of Behavioral Medicine, 39 (1), 4-15. doi: 10.1007/s12160-009-9153-0

Bakker, A. B., \& Schaufeli, W. B. (2008). Positive organizational behavior: Engaged employees in flourishing organizations. Journal of Organizational Behavior, 29 (2), 147-154.

Benos, D. J., Kirk, K. L., \& Hall, J. E. (2003). How to review a paper? Advances in Physiology Education, 27 (2), 47-52. doi: 10.1152/advan.00057.2002

Bercheid, E. (2003). The human's greatest strength: other humans. In L. G. Aspinwall \& U. M. Staudinger (Eds.), The psychology of human strengths. Fundamental questions and future directions for a positive psychology (pp. 37-48). Washington, DC: APA.

Beveridge, S. (2005). Children, families and schools. Developing partnerships for inclusive education. New York, NY: RoutledgeFalmer.

Bosticco, C., \& Thompson, T. L. (2005). Narratives and story-telling in coping with grief and bereavement. OMEGA Journal of Death and Dying, 51 (1), 1-16.

Cohn, M. A., \& Fredrickson, B. L. (2010). In search of durable positive psychology interventions: Predictors and consequences of long-term positive behavior change. The Journal of Positive Psychology: Dedicated to furthering research and promoting good practice, 5 (5), 355-366. doi: 10.1080/17439760.2010.508883.

Craven, R. G., \& Bodkin-Andrews, G. (2006). New solutions for addressing indigenous mental health: a call to counsellors to introduce the New Positive Psychology of Success. Australian Journal of Guidance and Counselling, 16 (1), 41-54. doi: 10.1375/ajgc.16.1.41

Creswell, J. W. (2009). Research design. Qualitative, quantitative, and mixed methods approaches. Los Angeles, CA: Sage.

Csikszentmihalyi, M. (2008). Flow. The psychology of optimal experience. New York, NY: HarperPerennial.

Darbyshire, P., MacDougall, C., \& Schiller, W. (2005). Multiple methods in qualitative research with children: more insight or just more? Qualitative Research, 5 (4), 417-436.

Davis, G. L., Hoffman, R. G., \& Quigley, R. (1988). Self-concept change and positive peer culture in adjudicated delinquents. Child and Youth Care Quarterly, 17 (3), 137-145.

Diener, E. (Ed.) (2009). The science of well-being. New York, NY: Springer.

Diener, E., Oishi, S., \& Lucas, R. E. (2009). Subjective well-being: the science of happiness and life satisfaction. In S. J. Lopez \& C. R. Snyder (Eds.), Oxford handbook of positive psychology (pp. 187-194). Oxford: Oxford University Press.

Diener, E., Suh, E. M., Lucas, R. E., \& Smith, H. L. (1999). Subjective well-being: Three decades of progress. Psychological Bulletin, 125 (2), 276-302.

Egan, R., Stockley, D., Brouwer, B., Tripp, D., \& Stechyson, N. (2009). Relationships between area of academic concentration, supervisory style, student needs and best practices. Studies in Higher Education, 34 (3), 337-345. doi: 10.1080/03075070802597143.

Emilsson, U. M. (2007). Supervision of Supervisors: On developing supervision in postgraduate education. Higher Education Research and Development, 26 (2), 163-179. doi: 10.1080/07294360701310797.

Enders, J. (2005). Border crossings: Research training, knowledge dissemination and the transformation of academic work. Higher Education, 49 (1/2), 119-133. doi: 10.1007/s10734-004-2917-3.

Ferres, N., Connell, J., \& Travaglione, A. (2004). Co-worker trust as a social catalyst for constructive employee attitudes. Journal of Managerial Psychology, 19 (6), 608-622. doi: 10.1108/02683940410551516.

Fredrickson, B. L. (2001). The role of positive emotions in positive psychology: The broaden-and-build theory of positive emotions. American Psychologist, 56 (3), 218-226.

Gable, S., \& Haidt, J. (2005). What (and why) is positive psychology? Review of General Psychology, 9, $103-110$.

Happo, I., Määttä, K., \& Uusiautti, S. (2012). Experts or good educators - or both? The development of early childhood expertise in Finland. Early Childhood Development and Care, 182 (3-4), $487-$ 504.

Hobfoll, S. E., Spielberger, C. D., Breznitz, S., Figley, C., Folkman, S., Lepper-Green, B., Meichenbaum, D., Milgram, N. A., Sandler, I., Sarason, I., \& van der Kolk, B. (1991). War-related stress: Addressing the stress of war and other traumatic events. American Psychologist, 46 (8), 848-855. 
Kaarina MÄÄTTÄ, Satu UUSIAUTTI. Two perspectives on caring research: Research on well-being and researcher well-being

PROBLEMS

OF EDUCATION

IN THE $21^{\text {st }}$ CENTURY Volume 66, 2015

38

Hoisko, S., Uusiautti, S., \& Määttä, K. (2014). How to overcome bullying at school? In K. Määttä \& S. Uusiautti (Eds.), Time for health education (pp. 101-114). Frankfurt am Main: Peter Lang.

Houston, D., Meyer, L. H., \& Paewai, S. (2006). Academic staff workloads and job satisfaction: Expectations and values in academe. Journal of Higher Education Policy and Management, 28 (1), 17-30. doi: 10.1080/13600800500283734.

Huebner, E. S., Gilman, R., Reschly, A. L., \& Hall, R. (2009). Positive schools. In S. J. Lopez \& C. R. Snyder (Eds.), The Oxford handbook of positive psychology (pp. 561-568) (2nd ed.) Oxford: Oxford University Press.

Hyvärinen, S., Uusiautti, S., \& Määttä, K. (2015). From a novice to an expert. Finnish female leaders' eventful career developments. Journal of Studies in Education, 5 (1), 1-26. doi:10.5296/jse. v5i1.6756.

Isen, A. M. (2003). Positive affect as a source of human strength. In L. G. Aspinwall \& U. M. Staudinger (Eds.), A psychology of human strengths. Fundamental questions and future directions for a positive psychology (pp. 179 - 196). Washington, DC: American Psychological Association.

Isen, A. M., \& Reeve, J. (2006). The influence of positive affect on intrinsic and extrinsic motivation: Facilitating enjoyment of play, responsible work behavior, and self-control. Motivation and Emotion, 29, 297-325.

Jiang, S., \& Winfree, L. T. (2006). Social support, gender, and inmate adjustment to prison life insights from a national sample. The Prison Journal, 86 (1), 32-55. doi: 10.1177/0032885505283876.

Kahneman, D., \& Krueger, A. B. (2006). Developments in the measurement of subjective well-being. The Journal of Economic Perspectives, 20 (1), 3-24.

Kahneman, D., Krueger, A. B., Schkade, D. A., Schwarz, N., \& Stone, A. A. (2004). A survey method for characterizing daily life experience: the day reconstruction method. Science, 306, 1776-1780.

Kangas, S., Uusiautti, S., \& Määttä, K. (2012). Social Interaction among Children with ASD. International Journal of Early Childhood Special Education, 3 (2), 160-174.

Karjalainen, S., Nyrhilä, A.-M., Määttä, K., \& Uusiautti, S. (2013). Going to school with narcolepsy Perceptions of families and teachers of children with narcolepsy. Early Child Development and Care, iFirst August, 14, 2013. doi: 10.1080/03004430.2013.821984.

Keskitalo, P., Uusiautti, S., \& Määttä, K. (2013). How to make the small indigenous cultures bloom? Special traits of Sámi education in Finland. Current Issues in Comparative Education, 15 (1), 52-62.

Kezar, A. J., \& Kinzie, J. L. (2006). Examining the ways institutions create student engagement: the role of mission. Journal of College Student Development, 47 (2), 149-172. doi: 10.1353/csd.2006.0018.

Kinjerski, V., \& Skrypnek, B. J. (2006). Creating organizational conditions that foster employee spirit at work. Leadership \& Organization Development Journal, 27 (4), 280-295. DOI: $10.1108 / 01437730610666037$.

Knapp, S. J., \& VandeCreek, L. (2006). Practical ethics for psychologists: A positive approach. Washington, DC: APA.

Koski-Heikkinen, A., Määttä, K., \& Uusiautti, S. (2014). The birth and development of vocational education teachers' (VET) professional identity. International Journal of Research Studies in Education, 3 (5), 446-463.

Kramer, R. M. (1999). Trust and distrust in organizations: Emerging perspectives, enduring questions. Annual Review of Psychology, 50, 569-598. doi: 10.1146/annurev.psych.50.1.569.

Kubiatko, M. (2013). On the problematic of "research islands" (Part 1). Problems of Education in the 21st Century, 53, 5-6.

Lakkala, S., Uusiautti, S., \& Määttä, K. (2014). How to make the neigbourhood school a school for all? Finnish teachers' perceptions of educational reform aiming toward inclusion. Journal of Research in Special Educational Needs, online First. doi: 10.1111/1471-3802.12055.

Liden, R. C., Wayne, S. J. \& Sparrowe, R. T. (2000). An examination of the mediating role of psychological empowerment on the relations between the job, interpersonal relationships, and work outcomes. Journal of Applied Psychology, 85 (3), 407 - 416.

Linley, A., Willars, J., \& Biswas-Diener, R. (2010). The strengths book. Be confident, be successful, and enjoy better relationships by realizing the best of you. Coventry: CAPP Press.

Liu, J., Siu, O. L., \& Shi, K. (2010), Transformational leadership and employee well-being: The mediating role of trust in the leader and self-efficacy. Applied Psychology: An International Review, 59 (3), 454-479. doi: 10.1111/j.1464-0597.2009.00407.x. 
Luthans, F. (2002). Positive organizational behavior. Developing and managing psychological strengths. Academy of Management Executive, 16 (1), 57-72.

Luthans, F., Avolio, B. J., Avey, J. B., \& Norman, S. M. (2007). Positive psychological capital: Measurement and relationship with performance and satisfaction. Personnel Psychology, 60 (3), 541-572.

Lähteenmäki, S. (2013). Miten elämä kantaa - narratiivinen tutkimus puhevammaisten CP-nuorten elämän tarinoista [Life carries on - Narrative research on the life stories of youth with CP and related speech disorders]. (PhD Diss., University of Lapland, Rovaniemi, Finland).

Magnusson, D., \& Mahoney, J. L. (2006). Holistinen lähestymistapa myönteisen kehityksen tutkimuksessa [Holistic approach in research of positive development]. In L. G. Aspinwall \& U. M. Staudinger (Eds.), Ihmisen vahvuuksien psykologia [A psychology of human strengths] (pp. 232-250). Helsinki: Edita.

Manathunga, C. (2005). The development of research supervision: "Turning the light on a private space". International Journal of Academic Development, 10 (1), 17-30. doi: 10.1080/13601440500099977.

Mayall, B. (2008). Conversations with children. Working with generational issues. In P. Christensen \& A. James (Eds.), Research with children: Perspectives and practices (pp. 109-122). New York, NY: Routledge.

Mayya, S. S., \& Roff, S. (2004). Students' perceptions of educational environment. Education for Health, 17 (3), 280-291. doi: 10.1080/13576280400002445.

McAllister, D. J. (1995). Affect- and cognition-based trust as foundations for interpersonal cooperation in organizations. Academy of Management Journal, 38 (1), 24-59.

McCallin, A., \& Nayar, S. (2012). Postgraduate research supervision: a critical review of current practice. Teaching in Higher Education, 17 (1), 63-74. doi: 10.1080/13562517.2011.590979.

Myers, D. G., \& Diener, E. (1995). Who is happy? Psychological Science, 6 (1), 10-19.

Määttä, K. (2012). The pedagogy of supervising doctoral theses. In K. Määttä (Ed.), Obsessed with the doctoral theses. Supervision and support in the phases of dissertation process (pp. 143-160). Rotterdam: Sense Publishers.

Määttä, K. (2014). Välittävä ohjaus väitöskirjatyössä [Caring supervision of doctoral thesis]. In K. Määttä \& S. Uusiautti (Eds.), Voimaa välittävästä tutkimuksesta. Kasvatusalan konferenssi 6.-7.10.2014 [Strength from caring research. Educational Conference 6-7 Oct 2014] (pp. 9-20). Rovaniemi: University of Lapland.

Määttä, K., Anglé, J., \& Uusiautti, S. (2014). How to have a long-lasting multicultural marriage? Introducing the accumulation theory of multicultural romantic relationships. Journal of Social Sciences (COES\&RJ-JSS), 3 (3), 381-398.

Määttä, K., Uusiautti, S., \& Määttä, M. (2014). A story of an ideal study process at the University of Lapland, Finland. Global Journal of Human Social Science, 14 (1), 83-89.

Otake, K., Shimai, S., Tanaka-Matsumi, J., Otsui, K., \& Fredrickson, B. L. (2006). Happy people become happier through kindness: a counting kindnesses intervention. Journal of Happiness Studies, 7 (3), 361-375.

Pajares, F. (2001). Toward a positive psychology of academic motivation. The Journal of Educational Research, 95 (1), 27-35.

Pietilä-Litendahl, P., \& Uusiautti, S. (2014). Finding empowerment through continuing training - Spanish Women's Perceptions. Journal of Studies in Education, 4 (1), 154-171. doi:10.5296/jse.v4i1.4800.

Prout, A. (2005). The future of childhood. London: RoutledgeFalmer.

Purdie, N., Tripcony, P., Boulton-Lewis, G., Fanshawe, J., \& Gunstone, A. (2000). Positive self-identity for indigenous students and its relationship to school outcomes. Canberra: Commonwealth of Australia.

Purtilo-Nieminen, S., \& Määttä, K. (2011). Admission to university - Narratives of Finnish open university students. International Journal of Continuing Education and Lifelong Learning, 3 (2), 43-55.

Quick, J. C. (1999). Occupational Health Psychology: The convergence of health and clinical psychology with public health and preventive medicine in an organizational context. Professional Psychology: Research and Practice, 30, 123-128.

Rantala, T., \& Määttä, K. (2011). Ten thesis of the joy of learning at primary schools. Early Child Development and Care, 182 (1), 87-105.

Rego, A., Ribeiro, N., Pina, M., \& Jesuino, J. C. (2011). How happiness mediates the organizational virtuousness and affective commitment relationship. Journal of Business Research, 64(5), 524532. 
Kaarina MÄÄTTÄ, Satu UUSIAUTTI. Two perspectives on caring research: Research on well-being and researcher well-being

PROBLEMS

OF EDUCATION

IN THE $21^{\text {st }}$ CENTURY

Volume 66, 2015

40

Richardson, J. T. E. (2005). Students' approaches to learning and teachers' approaches to teaching in higher education. Educational Psychology: An International Journal of Experimental Educational Psychology, 25(6), 673-680. doi: 10.1080/01443410500344720.

Roth, W. M. (2002). Editorial power/authorial suffering. Research in Science Education, 32, 215-240.

Ryff, C. D., \& Singer, B. (2003). Ironies of the human condition: well-being and health on the way to mortality. In L. G. Aspinwall \& U. M. Staudinger (Eds.), A psychology of human strengths. Fundamental questions and future directions for a positive psychology (pp. 271-288). Washington, DC: Apa.

Salmela, M., \& Uusiautti, S. (2013). Finnish straight-A graduates' perceptions of the smoothness of their study paths. Journal of Studies in Education, 3 (4), 21-41. doi:10.5296/jse.v3i4.4270.

Sandage, S. J., Seminary, B., Hill, P. C. \& Vang, H. C. (2003). Toward a multicultural positive psychology: Indigenous forgiveness and Hmong culture. The Counseling Psychologist, 31 (5), 564-592. doi: $10.1177 / 0011000003256350$.

Savukoski, M., Määttä, K., \& Uusiautti, S. (2014). How to use positive psychology to beat anorexia? In K. Määttä \& S. Uusiautti (Eds.), Time for health education (pp. 85-100). Frankfurt am Main: Peter Lang.

Schofield, P. (1998). It's true: happy workers are more productive. Works Management, 51 (12), 33-35.

Schreiner, L. A., Hulme, E., Hetzel, R., \& Lopez, S. J. (2009). Positive psychology on campus. In S. J. Lopez \& C. R. Snyder (Eds.), The Oxford handbook of positive psychology (pp. 569-578). 2nd edition. Oxford: Oxford University Press.

Seligman, M. E. P. (2009). Positive education: positive psychology and classroom interventions. Oxford Review of Education, 35 (3), 293-311. DOI: 10.1080/03051980902934563.

Seligman, M. E. P. (2011). Flourish. A visionary new understanding of happiness and well-being. New York, NY: FreePress.

Seligman, M. E. P., Steen, T. A., Park, N., \& Peterson, C. (2005). Positive psychology progress. Empirical validation of interventions. American Psychologist, 60 (5), 410-421.

Sipilä, A. K., \& Määttä, K. (2011). Can facilitated communication method support autistic people according to the facilitators' opinions? Psychology of Language and Communication, 15 (1), 2011, $1-26$.

Stein, N., Trabasso, T., Folkman, S., \& Richards, R. A. (1997). Appraisal and goal processes as predictors of psychological well-being in bereaved caregivers. Journal of Personality and Social Psychology, 72, 872-884.

Syväjärvi, A., Uusiautti, S., Perttula J., Stenvall, J., \& Määttä, K. (2014). The reification of caring leadership in knowledge organization. Research Journal of Organizational Psychology and Education Studies, 3 (2), 83-105.

Teddlie, C., \& Tashakkori, A. (2003). Major issues and controversies in the use of mixed methods in the social and behavioral sciences. In A. Tashakkori, \& C. Teddlie (Eds.), Handbook of mixed methods in social \& behavioral research (pp. 3-50). Thousand Oaks, CA: Sage.

Tenopir, C., Mays, R., \& Wu, L. (2011). Journal article growth and reading patterns. New Review of Information Networking, 16 (1), 4-22. doi: 10.1080/13614576.2011.566796.

Tugade, M. M., Fredrickson, B. L., \& Feldman Barrett, L. (2004). Psychological resilience and positive emotional granularity: Examining the benefits of positive emotions on coping and health. Journal of Personality, 72 (6), 1161-1190.

Turner, N., Barling, J., \& Zacharatos, A. (2002). Positive psychology at work. In C. R. Snyder \& S. J. Lopez (Eds.), Handbook of positive psychology (pp. 715-728). Oxford: Oxford University Press.

Uusiautti, S. (2008). "Tänään teen elämäni parhaan työn.” Työmenestys Vuoden Työntekijöiden kertomana. (PhD Diss., University of Lapland, Rovaniemi, Finland.)

Uusiautti, S. (2013). An action-oriented perspective on caring leadership: a qualitative study of higher education administrators' positive leadership experiences. International Journal of Leadership in Education: Theory and Practice, 16 (4), 482-496. doi: 10.1080/13603124.2013.770077.

Uusiautti, S. (2015). Menestyvä ja hyvinvoiva yritys positiivisen psykologian valossa. Yritysjohdon ja työntekijöiden käsityksiä menestyksestä [A successful enterprise showing well-being in the light of positive psychology. Leaders' and employees' perception of success]. Helsinki: BoD. 
Uusiautti, S. (2014). Tiedejulkaiseminen voiman ja välittämisen näyttämönä [Scientific publication, the scene of power and caring]. In K. Määttä \& S. Uusiautti (Eds.), Voimaa välittävästä tutkimuksesta [Strength from caring research] (pp. 45-54). Rovaniemi: University of Lapland.

Uusiautti, S. (2015). The pressure of academic publishing. In S. Uusiautti \& K. Määttä (Eds.), Critical eye on education. Tallinn: United Press Global, in press.

Uusiautti, S., \& Määttä, K. (2013a). Does success at work produce well-being and happiness or vice versa? The International Journal of Interdisciplinary Organizational Studies, 7 (3), 11-25.

Uusiautti, S., \& Määttä, K. (Eds.) (2013b). How to study children? Methodological solutions of childhood research. Rovaniemi: Lapland University Press.

Uusiautti, S., \& Määttä, K. (2013c). How to train good teachers in Finnish universities? Student teachers' study process and teacher educators' role in it. European Journal of Educational Research, 1 (4), 339-352.

Uusiautti, S., \& Määttä, K. (2013d). Significant trends in the development of Finnish teacher training from the 1860s to 2010. Education Policy Analysis Archives, 21 (59), 1-19.

Uusiautti S., \& Määttä, K. (2014). Alkuperäiskansan vahvuuksista menestymiseen - positiivisen psykologian näkökulmia saamelaisopetukseen [From the indigenous people's stregths to success - positive psychological viewpoints to Sámi education]. In P. Keskitalo, S. Uusiautti, E. Sarivaara, \& K. Määttä, K. (Eds.), Saamelaispedagogiikan ydinkysymysten äärellä [Core questions of the Sámi pedagogy] (pp. 137-156). Rovaniemi: Lapland University Press.

Uusiautti, S., \& Määttä, K. (2015). The psychology of becoming a successful worker. Research on the changing nature of achievement at work. New York, NY: Routledge.

Vanninen, P., \& Määttä, K. (2013). Secondary education students with reading disability - findings from two remedial training experiments. Studies for the Learning Society, 3 (1-2). Doi: 10-2478/sls2013-0003.

Webster-Stratton, C., \& Reid, M. J. (2004). Strengthening social and emotional competence in young children-The foundation for early school readiness and success. Infants and Young Children, 17 (2), 96-113.

Winter, R., \& Sarros, J. (2002). The academic work environment in Australian universities: A motivating place to work? Higher Education Research \& Development, 21 (3), 241-258. doi: 10.1080/0729436022000020751.

Youssef, C. M., \& Luthans, F. (2007). Positive Organizational Behavior in the workplace: The impact of hope, optimism, and resilience. Journal of Management, 33 (5), 774-800. doi: $10.1177 / 0149206307305562$.

Äärelä, T., Uusiautti, S., \& Määttä, K. (2014). Young prisoners' experiences of the positive factors of small group teaching during their basic education - toward the pedagogy of preventing social exclusion. Journal of Studies in Education, 4(4), 45-67. doi: 10.5296/jse.v4i4.6452

Advised by Laima Railiené, Šiauliai University, Lithuania

Received: April 20, 2015

Accepted: June 25, 2015

\begin{tabular}{ll} 
Kaarina Määttä & PhD, Professor, Vice-Rector, University of Lapland, PO Box 122, 96101 Rovaniemi, \\
& Finland. \\
& E-mail: Kaarina.Maatta@ulapland.fi \\
& Website: http://www.ulapland.fi/KaarinaMaatta \\
\hline Satu Uusiautti & PhD, Adjunct Professor, Researcher, University of Lapland, PO Box 122, 96101 \\
& $\begin{array}{l}\text { Rovaniemi, Finland. } \\
\text { E-mail: satu_uusiautt@@hotmail.com }\end{array}$
\end{tabular}

